\title{
Potensi Daun Pacar Air (Impatiens balsamina L.) dalam Menghambat Pertumbuhan Jamur Rhizopus oryzae L.
}

\author{
Morina Adfa ${ }^{*}$, Munifilia Ekasari ${ }^{2}$, Avidlyandi Avidlyandi ${ }^{2}$, Rochmah Supriati ${ }^{3}$, Salprima Yudha S. ${ }^{1}$ \\ IJurusan Kimia, Fakultas Matematika dan Ilmu Pengetahuan Alam, Universitas Bengkulu, Bengkulu, \\ Indonesia \\ 2Program Studi Magister Kimia, Fakultas Matematika dan Ilmu Pengetahuan Alam, Universitas \\ Bengkulu, Bengkulu, Indonesia \\ 3Jurusan Biologi, Fakultas Matematika dan Ilmu Pengetahuan Alam, Universitas Bengkulu, Bengkulu, \\ Indonesia
}

Corresponding Author:

Morina Adfa

morina@unib.ac.id

Received: February 2021

Accepted: August 2021

Published: September 2021

CMorina Adfa et al. This is an open-access article distributed under the terms of the Creative Commons Attribution License, which permits unrestricted use, distribution, and reproduction in any medium, provided the original author and source are credited.

\begin{abstract}
Pacar air (Impatiens balsamina L.) plant belongs to the Balsaminaceae family and is used as an indigenous medicine in Asia for fingernail inflammation, fractures, and rheumatism treatments. Moreover, the antipruritic, antianaphylactic, antifungal, antibacterial, and antitumor activities of some compounds, especially phenolics and quinones from this plant have been studied extensively. Therefore, this study aims to determine the antifungal activity of Pacar air leaves (Impatiens balsamina L.) methanol extract against Rhizopus oryzae $\mathrm{L}$. and the $\mathrm{IC}_{50}$ value. The results showed that an increase in the concentrations of I. balsamina L. leaves methanol extract significantly raised the fungal growth. Furthermore, the extract inhibition against $R$. oryzae L. at various concentrations of $0.5 ; 0.7 ; 0.9 ; 1.1 ;$ and $1.3 \% \mathrm{w} / \mathrm{v}$ were $10,21.9$, $58.06,68.06$, and $79.72 \%$, respectively, while the $\mathrm{IC}_{50}$ value was $0.896 \%$. Hence, the presence of naphthoquinones and other secondary metabolites are responsible for its antifungal activity. Based on these results, the antifungal potential of I. balsamina L. leaves against soft-rot fungi is useful in the future.
\end{abstract}

Keywords: Impatiens balsamina L., Pacar air, IC50, antifungal activity, naphthoquinones

\section{Pendahuluan}

Kayu merupakan biopolimer yang sebagian besar tersusun dari selulosa, hemiselulosa, lignin, dan beberapa senyawa metabolit sekunder. Salah satu sifat dari kayu adalah dapat mengalami peningkatan jumlah kadar air sehingga dapat menyebabkan kayu mudah diserang oleh jamur pelapuk kayu ${ }^{[1]}$.

Jamur yang berperan dalam biodegradasi biomassa lignoselulosa dibagi menjadi tiga kelompok utama berdasarkan dari tipe pelapukan yang disebabkannya, yaitu jamur pelapuk putih (white rot), jamur pelapuk coklat (brown rot), dan jamur pelapuk lunak (soft rot). Jamur pelapuk putih dan jamur pelapuk coklat termasuk kedalam kelompok Basidiomycetes, sedangkan jamur pelapuk lunak termasuk kedalam kelompok Ascomycetes. Jamur pelapuk coklat secara selektif mendegradasi selulosa dan hemiselulosa, hanya sedikit mendegradasi lignin sehingga meninggalkan residu berwarna kecoklatan. Sedangkan jamur pelapuk putih 
memiliki kemampuan mendegradasi lignin, selulosa, dan hemiselulosa akibatnya kayu akan menjadi lebih pucat dibandingkan kayu normal. Jamur pelapuk lunak juga dapat mendegradasi selulosa dan hemiselulosa pada kayu yang mempunyai kadar air dan nitrogen yang tinggi, seperti pada kayu lantai rumah, jendela dan pagar. Akibat dari serangan jamur pelapuk lunak, permukaan kayu menjadi lebih lunak secara bertahap dan warna kayu menjadi lebih gelap $[2,3,4,5]$.

Kondisi lingkungan yang lembab dan proses pengeringan yang kurang sempurna pada kayu menjadi penyebab mudahnya kayu diserang jamur pelapuk. Kondisi tersebut lambat laun dapat menyebabkan kerusakan pada kayu, yang pada akhirnya akan menurunkan kualitas, nilai keawetan dan ketahanan kayu ${ }^{[6]}$. Munculnya serangan jamur pelapuk kayu ditandai dengan tumbuhnya miselium jamur pelapuk pada permukaan kayu. Hifa jamur akan mengeluarkan enzim untuk mendegradasi lignin, selulosa, dan hemiselulosa seperti enzim laccase, lignin peroksidase, Mn peroksidase, selulase, protease, amilase, xylanase, dll. Rhizopus oryzae L. merupakan salah satu soft rot dari kelompok Zygomycetes yang dapat menghasilkan enzim selulase, sehingga jamur $R$. oryzae L. memiliki kemampuan untuk mendegradasi kayu ${ }^{[7]}$.

Salah satu upaya untuk mengawetkan kayu agar terhindar dari organisme perusak adalah menggunakan bahan kimia pengawet kayu, seperti CCB (chopper-chrome-boron). Bahan kimia pengawet kayu mempunyai aktivitas fungisida dan insektisida, namun aktivitas pengawetan kayu menggunakan bahan kimia akan menghasilkan limbah, jika limbah tidak diolah dengan baik akan menyebabkan pencemaran lingkungan dan gangguan kesehatan ${ }^{[8]}$. Bahan pengawet kayu alami sudah banyak dilaporkan, seperti penggunaan asap cair dari biomassa dan ekstrak dari beberapa tumbuhan. Asap cair dan ekstrak beberapa tumbuhan Indonesia telah terbukti mengandung senyawa aktif yang dapat menghambat serangan jamur pelapuk kayu, seperti contohnya asap cair batang kayu gadis (Cinnamomum parthenoxylon) dapat menghambat pertumbuhan jamur pelapuk kayu
(Schizophyllum commune and Fomitopsis palustris ${ }^{[9]}$. Karena masih terbatasnya informasi pengawet kayu alami dari tumbuhan Indonesia, maka pencarian sumber-sumber pengawet alami kayu yang lebih ampuh dan ramah lingkungan harus tetap dilakukan.

Tanaman Pacar air (Impatiens balsamina L.) dari famili Balsaminacea merupakan tanaman hias yang popular dikalangan masyarakat Indonesia. Secara tradisional daun tanaman Pacar air dimanfaatkan untuk mengobati luka pada kuku, didukung oleh publikasi sebelumnya bahwa ekstrak daun Pacar air memiliki aktivitas anti bakteri terhadap bakteri Porphyromonas gingivalis ${ }^{[10]}$, Staphylococcus aureus, Bacillus cereus $^{[11]}$ Propionibacterium acnes dan Staphylococcus epidermidis ${ }^{[12]}$. Daun Pacar air juga memiliki aktivitas antijamur terhadap jamur Aspergillus fumigatus, Fusarium oxysporum, dan Microsporum gypseum. Senyawa kimia yang memiliki aktivitas anti bakteri dan antijamur dari daun Pacar air yang dilaporkan adalah 2metoksi-1,4 naftokuinon ${ }^{[13]}$. Namun dari penelusuran literatur belum ada laporan aktivitas antijamur dari daun Pacar air terhadap jamur pelapuk kayu. Pada artikel ini dilaporkan aktivitas ekstrak metanol daun Pacar air dalam menghambat pertumbuhan jamur Rhizopus oryzae L.

\section{Metodologi Penelitian}

\section{Bahan kimia}

Sampel tanaman pada penelitian ini adalah daun Pacar air (Impatiens balsamina L.). Spesimen uji dalam penelitian ini adalah jamur pelapuk lunak Rhizopus oryzae L. Bahan kimia yang digunakan adalah media PDA (Potato Dextrose Agar) Merck, akuades, metanol (Brataco), dimetil sulfoksida (DMSO) Merck, spritus, dan etanol $70 \%$.

\section{Peralatan}

Peralatan yang digunakan adalah rotary evaporator (Heidolph), oven (Philips), autoklaf (AIP), inkubator (Froilabo), laminar air flow (Telster AV-100), neraca analitik (aeADAM), hot plate (Jenway 1000), lampu spritus, cawan petri (Normax, diameter luar $100 \mathrm{~mm}$ x $20 \mathrm{~mm}$ ), 
jarum ose, cork borer $5 \mathrm{~mm}$, water bath, magnetic stirrer, dan peralatan gelas lainnya.

\section{Prosedur penelitian}

\section{Persiapan sampel dan ekstraksi daun Pacar air (Impatiens balsamina L.)}

Sampel daun Pacar air diambil dari Desa Tanjung Dalam, Kecamatan Curup Selatan, Kabupaten Rejang Lebong, kemudian dibawa ke laboratorium untuk dibersihkan dari pengotor. Setelah bersih lalu dipotong kecil kecil dan dikering anginkan selama 1 minggu. Sebanyak $1.34 \mathrm{Kg}$ daun Pacar air yang telah kering angin dimasukkan kedalam 5 buah botol gelap dan dimaserasi dengan metanol (10.3 L) selama 4 hari. Hasil maserasi disaring, kemudian pelarutnya diuapkan menggunakan rotary evaporator pada suhu $45-50 \quad{ }^{\circ} \mathrm{C}$ untuk mendapatkan ekstrak pekat metanol daun Pacar air. Selanjutnya sampel daun Pacar air dimaserasi kembali dengan metanol menggunakan volume yang sama dengan maserasi tahap satu[14]. Proses remaserasi dilakukan 6 kali hingga pelarut metanol hasil maserasi tidak berwarna (bening), lalu semua ekstrak pekat metanol daun Pacar air digabung dan siap digunakan untuk uji aktivitas anti jamur Rhizopus oryzae L.

\section{Uji aktivitas antijamur}

Pembuatan media tumbuh dilakukan dengan melarutkan $39 \mathrm{~g}$ PDA dengan $1 \mathrm{~L}$ akuades yang diletakkan di dalam Erlenmeyer tertutup kemudian dilakukan pemanasan menggunakan hotplate serta dilakukan pengadukan menggunakan magnetic stirrer hingga homogen. Selanjutnya larutan PDA disterilisasi pada autoklaf dengan suhu $121^{\circ} \mathrm{C}$ dan tekanan 103.4 $\mathrm{kPa}$ (15 psi) selama 15 menit ${ }^{[15]}$. Dalam pengujian ini ekstrak metanol daun Pacar air dibuat dalam konsentrasi $0.5 \% ; 0.7 \% ; 0.9 \% ; 1.1 \%$; dan $1.3 \%$ $\mathrm{b} / \mathrm{v}$. Ekstrak metanol daun Pacar air yang telah ditimbang sesuai dengan peruntukan masingmasing konsentrasi kemudian dilarutkan kedalam 0.5 mL DMSO dan dicampurkan kedalam $16.5 \mathrm{~mL}$ media PDA yang telah disterilkan, lalu media yang sudah tercampur ekstrak dibiarkan memadat. Cawan petri yang berisi $16.5 \mathrm{~mL}$ media PDA + 0.5 mL DMSO saja digunakan sebagai kontrol. Setelah media memadat, selanjutnya dengan menggunakan cork borer (diameter $5 \mathrm{~mm}$ ) dilakukan pengambilan miselium jamur Rhizopus oryzae L. yang telah diremajakan sebelumnya kemudian diletakkan dibagian tengah permukaan cawan petri lalu diinkubasi pada suhu $25^{\circ} \mathrm{C}$ sampai jamur pada kontrol memenuhi permukaan cawan petri. Kegiatan pengujian dilakukan sebanyak 4 kali ulangan.

Setelah pertumbuhan miselium jamur pada kontrol memenuhi seluruh permukaan cawan petri, maka diukur diameter pertumbuhan miselium jamur pada semua konsentrasi uji menggunakan penggaris (skala $\mathrm{mm}$ ), lalu dihitung persentase daya hambat pertumbuhan jamur dengan menggunakan persamaan berikut[16]:

Daya hambat $(\%)=\frac{\mathrm{Da}-\mathrm{Db}}{\mathrm{Da}} \times 100 \%$

Keterangan:

$\mathrm{Da}=$ diameter pertumbuhan miselium pada kontrol (mm)

$\mathrm{Db}=$ diameter pertumbuhan miselium pada sampel uji (mm)

\section{Analisis data}

Data persentase daya hambat pertumbuhan jamur dianalisis menggunakan uji one way ANOVA dan dilanjutkan dengan uji Duncan menggunakan aplikasi SPSS 21 dengan taraf kepercayaan $95 \%$. IC50 pertumbuhan jamur ditentukan menggunakan analisis probit ${ }^{[9]}$.

\section{Hasil dan Diskusi}

\section{Ekstraksi daun Pacar air (Impatiens balsamina} L.)

Maserasi $1.34 \mathrm{Kg}$ daun Pacar air menggunakan 10.3 L pelarut metanol didapatkan hasil berupa ekstrak encer berwarna hijau tua. Proses remaserasi dilakukan berulang hingga pelarut hasil maserasi menjadi bening. Seluruh hasil maserasi disatukan kemudian pelarut diuapkan menggunakan rotary evaporator diperoleh 
ekstrak pekat metanol daun Pacar air sebanyak 209.03 g dengan rendemen $15.6 \%$. Ekstrak pekat metanol daun Pacar air selanjutnya digunakan untuk uji aktivitas antijamur terhadap Rhizopus oryzae L.

Aktivitas anti jamur ekstrak metanol daun Pacar air (Impatiens balsamina L.) terhadap Rhizopus oryzae L.

Untuk melihat aktivitas anti jamur ekstrak metanol daun Pacar air terhadap jamur Rhizopus oryzae L. dilakukan dengan mengamati dan mengukur diameter pertumbuhan jamur pada media yang telah diberi perlakukan ekstrak metanol daun Pacar air dengan berbagai tingkatan konsentrasi. Ekstrak metanol daun Pacar air mengandung senyawa metabolit sekunder yang diduga bersifat anti jamur terhadap $R$. oryzae L. Diameter rata-rata pertumbuhan jamur $R$. oryzae L. dari 4 kali ulangan disajikan pada Tabel 1.

Pada Tabel 1 dapat dilihat nilai rata-rata diameter pertumbuhan miselium jamur $R$. oryzae L. pada kontrol adalah $9 \mathrm{~cm}$. Diameter pertumbuhan jamur setelah pemberian ekstrak metanol daun Pacar air memiliki perbedaan ukuran sesuai dengan tingkat variasi konsentrasi yang diberikan (Gambar 1).

Tabel 1. Diameter pertumbuhan miselium jamur Rhizopus oryzae L. (cm) pada PDA kontrol dan PDA dengan berbagai variasi konsentrasi ekstrak metanol daun Pacar air

\begin{tabular}{|c|c|c|c|c|c|}
\hline \multirow{2}{*}{$\begin{array}{c}\text { Konsentrasi Ekstrak } \\
\text { MeOH Daun Pacar } \\
\text { Air }\end{array}$} & \multicolumn{4}{|c|}{$\begin{array}{c}\text { Diameter Pertumbuhan Jamur } \\
\text { Pengulangan ke- }\end{array}$} & \multirow{2}{*}{$\begin{array}{l}\text { Rata-Rata Diameter } \\
\text { Pertumbuhan } \\
\text { R. oryzae } \mathrm{L} .(\mathrm{cm}) \pm \mathrm{SD}\end{array}$} \\
\hline & I & II & III & IV & \\
\hline Kontrol & 9 & 9 & 9 & 9 & $9.000 \pm 0.0000$ \\
\hline $0.5 \%$ & 8.1 & 8.2 & 8.1 & 8 & $8.100 \pm 0.0816$ \\
\hline $0.7 \%$ & 7 & 7.2 & 7.1 & 7 & $7.075 \pm 0.0957$ \\
\hline $0.9 \%$ & 4.1 & 3.9 & 3.6 & 3.5 & $3.775 \pm 0.2754$ \\
\hline $1.1 \%$ & 2.8 & 2.7 & 2.9 & 3.1 & $2.875 \pm 0.1708$ \\
\hline $1.3 \%$ & 2 & 1.8 & 1.7 & 1.8 & $1.825 \pm 0.1258$ \\
\hline
\end{tabular}

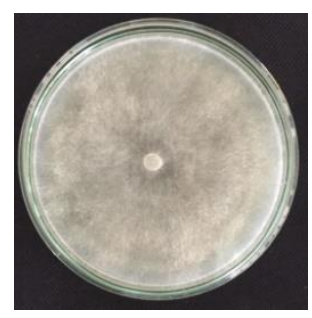

(A)

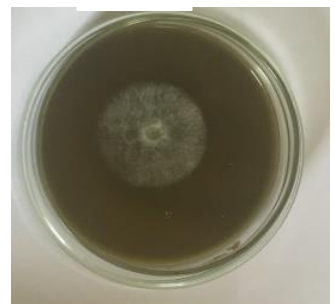

(D)

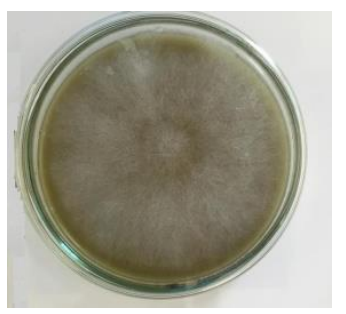

(B)

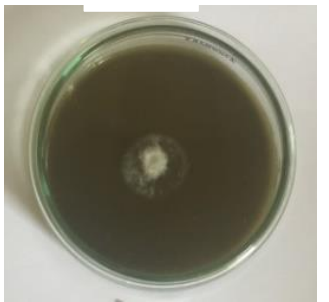

(E)

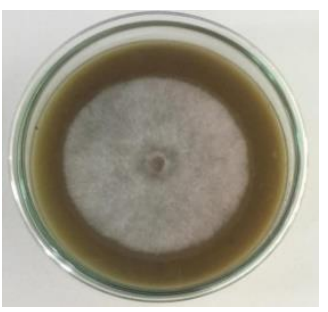

(C)

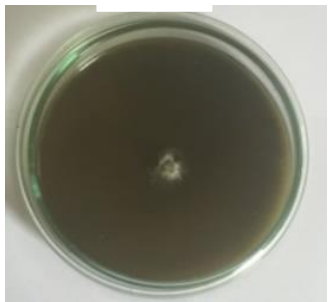

(F)

Gambar 1. Pertumbuhan miselium jamur Rhizopus oryzae L. setelah pemberian ekstrak metanol daun Pacar air (Impatiens balsamina L.) pada berbagai konsentrasi uji (a) kontrol, (b) $0.5 \%$, (c) $0.7 \%$, (d) $0.9 \%$, (e) $1.1 \%$ dan (f) $1.3 \% \mathrm{~b} / \mathrm{v}$. 


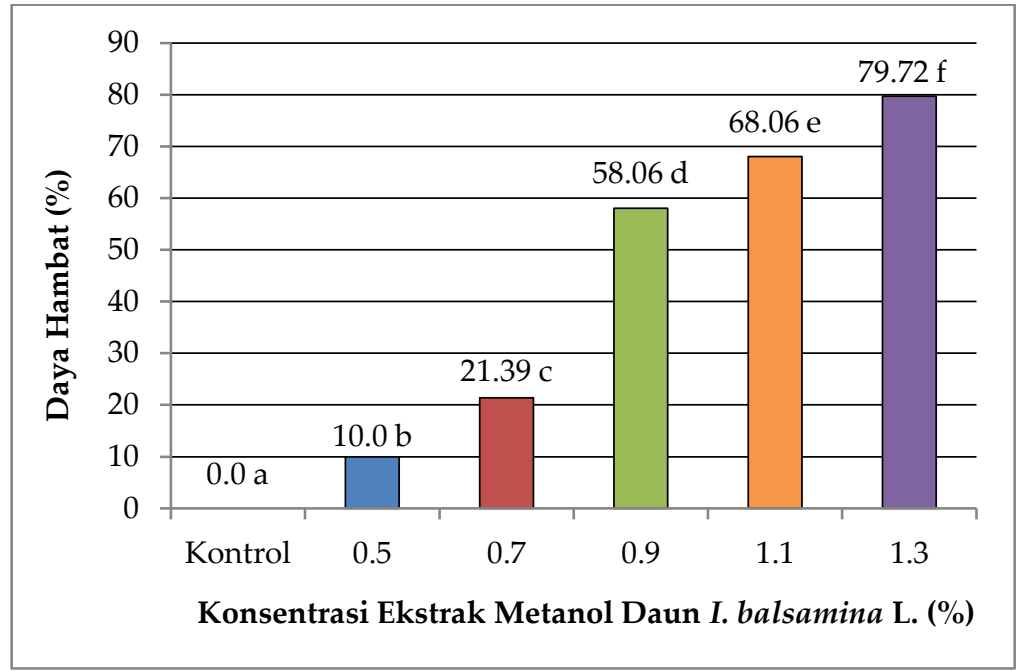

Gambar 2. Grafik persentase daya hambat pertumbuhan jamur Rhizopus oryzae L. terhadap variasi konsentrasi ekstrak metanol daun Pacar air (Impatiens balsamina L.).

Pada konsentrasi $0.5 \%$ ekstrak metanol daun Pacar air menunjukkan nilai rata-rata diameter pertumbuhan miselium jamur $R$. oryzae L. terbesar yaitu $8.10 \mathrm{~cm}$, sedangkan nilai rata-rata diameter pertumbuhan jamur $R$. oryzae $\mathrm{L}$. terkecil pada konsentrasi $1.3 \%$ dengan nilai $1.825 \mathrm{~cm}$. Berdasarkan Tabel 1, nilai rata-rata diameter pertumbuhan jamur $R$. oryzae L. mengalami penurunan seiring dengan bertambahnya konsentrasi ekstrak metanol daun Pacar air yang diberikan. Dari hasil pengukuran diameter pertumbuhan jamur $R$. oryzae L. dapat dihitung nilai persentase ratarata daya hambat pertumbuhan jamur yang disebabkan oleh ekstrak metanol daun Pacar air (Gambar 2).

Ekstrak metanol daun Pacar air menunjukkan penghambatan yang signifikan terhadap pertumbuhan miselium jamur $R$. oryzae L. pada media uji yang diberi perlakuan ekstrak dan kontrol (Gambar 1 dan 2). Penghambatan ekstrak metanol daun Pacar air terhadap pertumbuhan $R$. oryzae $\mathrm{L}$. pada berbagai konsentrasi uji $0.5 ; 0.7 ; 0.9 ; 1.1$, dan $1.3 \%$ b/v berturut-turut adalah $10 ; 21.9 ; 58.06 ; 68.06$; dan $79.72 \%$. Pada Gambar 2 terlihat jelas bahwa persentase daya hambat pertumbuhan jamur $R$. oryzae L. terhadap pemberian ekstrak metanol daun Pacar air mengalami kenaikan seiring dengan penambahan konsentrasi ekstrak metanol daun Pacar air. Nilai daya hambat terbesar $79.72 \%$ pada konsentrasi ekstrak 1.3\%, sedangkan daya hambat terkecil $10.00 \%$ pada pemberian ekstrak $0.5 \%$. Sejalan dengan Adfa et al (2020) bahwa semakin besar konsentrasi senyawa antijamur yang diaplikasikan, maka aktivitas antijamur senyawa tersebut semakin besar pula ${ }^{[9]}$.

Daya hambat pertumbuhan jamur setelah pemberian ekstrak metanol daun Pacar air dipengaruhi oleh kandungan metabolit sekundernya. Senyawa golongan kumarin (kumarin dan skopoletin), dan senyawa golongan naftokuinon (2-metoksi 1,4naftokuinon, 2-hidroksi 1,4-naftokuinon, metilen-3,3'-bilawson) telah diisolasi dan dilaporkan sebagai kandungan utama daun Pacar air. Senyawa golongan flavonoid diantaranya kaempferol, kaempferol-3glucoside, quercetin, rutin, astragalin, nicotiflorin, naringenin) telah dilaporkan dari bunga dan daun Pacar air. Beberapa senyawa fenolik (asam galat, asam gentisik, asam syringik, asam 3-hidroksisinamat, cis asam sinapik) juga telah diisolasi dari daun Pacar $\operatorname{air}^{[17]}$.

Efektivitas antijamur metabolik sekunder tergantung dari jenis molekul aktifnya, meliputi inhibitor enzim, gangguan dinding sel dan struktur membran sel, aktivitas antioksidan, atau menyebabkan perubahan morfologi hifa ${ }^{[18]}$. 
Didukung penelitian sebelumnya yang melaporkan bahwa senyawa naftokuinon dari daun Pacar air menunjukkan aktivitas antimikroba yang sangat baik, senyawa 2metoksi 1,4-naftokuinon mempunyai aktivitas antimikroba yang paling baik diantara 2 senyawa naftokuinon lainnya. Senyawa 2metoksi 1,4-naftokuinon yang diisolasi dari daun Pacar air berpotensi sebagai antifungi terhadap jamur Candida albicans, Aspergillus fumigatus, A. niger, Cryptococcus neoformans, Fusarium oxysporum, Trichophyton rubrum, dan Microsporum gypseum, serta memperlihatkan aktivitas antibakteri terhadap Bacillus subtilis, $B$. cereus, Staphylococcus aureus, Aeromonas salmonicida dan Aquaspirilium serpens. Bakteri Aeromonas salmonicida A449 dan jamur Aspergillus fumigatus adalah jenis yang paling sensitive terhadap 2-metoksi 1,4-naftokuinon. Salah satu mekanisme aksi antimikroba 2metoksi 1,4-naftokuinon adalah mengganggu rantai respirasi mitokondria mikroba karena kemiripan strukturnya dengan Koenzim-Q10. Senyawa 2-metoksi 1,4-naftokuinon meningkatkan konsumsi oksigen dari mikroorganisme tetapi tidak mengaktifkan ATPase mitokondria mikroba ${ }^{[13,19]}$. Flavonoid juga banyak terdapat pada daun Pacar air yang juga dilaporkan dapat menghambat pertumbuhan jamur dengan berbagai mekanisme aksi, diantaranya gangguan membran plasma, induksi disfungsi mitokondria, menghambat pembentukan dinding sel/pembelahan sel, dan juga dapat menghambat sintesis RNA dan protein ${ }^{[20]}$.
Uji ANOVA satu arah dengan derajat kepercayaan 95\% dengan SPSS 21 didapat nilai Fhitung $>F_{\text {tabel }}(1573.851>2.77285)$, maka Ho ditolak dan $\mathrm{H}_{1}$ diterima. Data analisis statistik menunjukkan terdapat perbedaan yang signifikan pemberian ekstrak metanol daun Pacar air terhadap persentase daya hambat pertumbuhan jamur $R$. oryzae L. Adanya pengaruh nyata yang ditunjukkan dari hasil analisis uji one way ANOVA maka analisis dilanjutkan dengan uji Duncan untuk melihat apakah ada perbedaan yang signifikan pemberian ekstrak metanol daun Pacar air antar perlakuan (antar konsentrasi) dan kontrol terhadap persentase daya hambat pertumbuhan jamur R. oryzae L.

Hasil analisis uji Duncan diperoleh nilai notasi kontrol (a) yang berbeda nyata dari semua perlakuan pemberian ekstrak metanol daun Pacar air (notasi b, c, d, e, dan f) terhadap persentase daya hambat pertumbuhan jamur $R$. oryzae L. (Gambar 2). Hal ini menunjukkan adanya perbedaan nyata antar perlakuan dan kontrol terhadap persentase daya hambat pertumbuhan jamur $R$. oryzae L. Berdasarkan analisis probit $\left(\mathrm{y}=5.3435 \mathrm{x}+5.2547\right.$ dan $\mathrm{R}^{2}=$ 0.9706) diperoleh nilai IC 50 pada konsentrasi $0.896 \% \mathrm{~b} / \mathrm{v}^{[21]}$, dimana rata-rata pertumbuhan jamur $R$. oryzae L. akan dihambat $50 \%$ ketika pemberian ekstrak metanol daun Pacar air pada konsentrasi $0.896 \%$ b/v (Gambar 3).

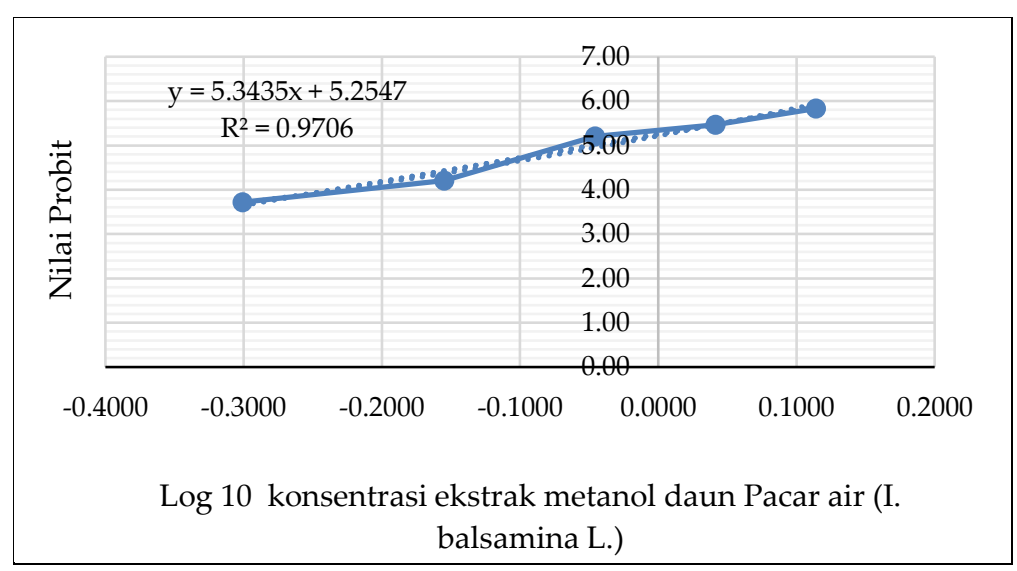

Gambar 3. Grafik persamaan regresi linier log 10 konsentrasi ekstrak metanol daun Pacar air terhadap nilai probit persentase daya hambat pertumbuhan jamur Rhizopus oryzae $\mathrm{L}$. 


\section{Kesimpulan}

Hasil penelitian menunjukkan bahwa ekstrak metanol daun Pacar air (Impatiens balsamina L.) dapat menghambat pertumbuhan jamur Rhizopus oryzae L. pada berbagai tingkatan konsentrasi uji. Berdasarkan hasil analisis uji one way ANOVA dan uji lanjut Duncan diperoleh pemberian variasi konsentrasi ekstrak metanol daun Pacar air berbeda nyata antar perlakuan dan kontrol, dengan persentase daya hambat terbesar pada konsentrasi $1.3 \% \mathrm{~b} / \mathrm{v}$ dengan nilai $79.72 \%$. Dari analisis probit diperoleh nilai IC $_{50}$ adalah $0.896 \% \mathrm{~b} / \mathrm{v}$. Diduga kandungan metabolit sekunder yang terdapat didalam ekstrak metanol daun Pacar air berperan penting terhadap aktivitas ini terutama senyawa-senyawa naftokuinon yang merupakan komponen utamanya. Penelitian sedang dilanjutkan untuk menguji aktivitas senyawa tunggal hasil isolasi dari ekstrak metanol daun Pacar air terhadap jamur pelapuk kayu, sehingga diharapkan daun Pacar air dapat digunakan sebagai bio fungisida dimasa mendatang.

\section{Daftar Pustaka}

1. Djarwanto, D. \& Suprapti, S., Kemampuan pelapukan 10 strain jamur pada lima jenis kayu asal Kalimantan Timur. J. Penelit. Has. Hutan, 32(4): 263-270 (2014).

2. Schmidt, O., Wood and tree fungi: Biology, damage, protection, and use. Springer Berlin Heidelberg, (2006).

3. Leonowicz, A., Matuszewska, A., Luterek, J., Ziegenhagen, D., Wojtaś-Wasilewska, M., Cho, N.-S., Hofrichter, M., et al., Biodegradation of lignin by white rot fungi. Fungal Genet. Biol., 27(2-3): 175-185 (1999).

4. Isroi., Millati, R., Syamsiah, S., Niklasson, C., Cahyanto, M. N., Lundquist, K. \& Taherzadeh, M. J., Biological pretreatment of lignocelluloses with white-rot fungi and its applications: a review. BioResources, 6(4): 5224-5259 (2011).

5. Blanchette, R. A., Degradation of the lignocellulose complex in wood. Can. J. Bot., 73(S1): 999-1010 (1995).
6. Astiti, N. P. A., Efektivitas ekstrak daun jati (Tectona grandis L. F.) dalam menghambat pertumbuhan jamur Hormiscium Sp. J. Bumi Lestari, 15(1): 66-70 (2015).

7. Kupski, L., de Carvalho Silvello, M. A., Fontes, M. R. V., Lima, T. S., Treichel, H. \& Badiale Furlong, E., R. oryzae cellulases: a new approach to degrading lignocellulosic material. J. Food Biochem., 39(2): 129-138 (2015).

8. Wardiha, M. W. \& Dibya, I. K. Y. P., Karakteristik limbah pengawet bambu petung dan gewang yang mengandung boron dan copper-chrome-boron serta alternatif pengelolaannya. J. Pemukim., 12(2): 64-69 (2017).

9. Adfa, M., Romayasa, A., Kusnanda, A. J., Avidlyandi, A., Yudha S., S., Banon, C. \& Gustian, I., Chemical components, antitermite and antifungal activities of Cinnamomum parthenoxylon wood vinegar. J. Korean Wood Sci. Technol., 48(1): 107-116 (2020).

10. Sapara, T. U., Waworuntu, O. \& Juliatri., Efektivitas antibakteri ekstrak daun pacar air (Impatiens balsamina L.) terhadap pertumbuhan Porphyromonas gingivalis. Pharmacon, 5(4): 10-17 (2016).

11. Adfa, M., Senyawa antibakteri dari daun pacar air (Impatiens balsamina Linn.). J. Gradien, 4(1): 318-322 (2008).

12. Ismarani, D., Pratiwi, L. \& Kusharyanti, I., Formulasi gel pacar air (Impatiens balsamina Linn.) Terhadap Propionibacterium acnes dan Staphylococcus epidermidis. Pharm. Sci. Res., 1(1): 30-45 (2014).

13. Yang, X., Summerhurst, D. K., Koval, S. F., Ficker, C., Smith, M. L. \& Bernards, M. A., Isolation of an antimicrobial compound from Impatiens balsamina L. using bioassay-guided fractionation. Phyther. Res., 15(8): 676-680 (2001).

14. Adfa, M., Kusnanda, A. J., Saputra, W. D., Banon, C., Efdi, M. \& Koketsu, M., Termiticidal activity of Toona sinensis wood vinegar against Coptotermes curvignathus Holmgre. Rasayan J. Chem., 
10(4): 1088-1093 (2017).

15. Herliyana, E. N., Maryam, L. F. \& Hadi, Y. S., Schizophyllum commune Fr. sebagai jamur uji ketahanan kayu Standar Nasional Indonesia pada empat jenis kayu rakyat: Sengon (P. falcataria), Karet (H. brasiliensis), Tusam (P. merkusii), Mangium (A. mangium). J. Silvikultur Trop., 2(3): 176-180 (2011).

16. Teoh, Y. P., Mashitah, M. D. \& Salmiah, U., Antifungal activities of selected wooddegrading fungi of rubberwood. J. Trop. For. Sci., 27(3): 325-333 (2015).

17. Szewczyk, K., Phytochemistry of the genus impatiens (Balsaminaceae): a review. Biochem. Syst. Ecol., 80: 94-121 (2018).
18. Broda, M., Natural compounds for wood protection against fungi-a review. Molecules, 25(15): 3538 (2020).

19. Sakunphueak, A. \& Panichayupakarananta, P., Comparison of antimicrobial activities of naphthoquinones from Impatiens balsamina. Nat. Prod. Res., 26(12): 1119-1124 (2012).

20. Aboody, M. S. Al. \& Mickymaray, S., Antifungal efficacy and mechanisms of flavonoids. Antibiotics, 9(2): 45 (2020).

21. Sakuma, M., Probit analysis of preference data. Appl. Entomol. Zool., 33(3): 339-347 (1998). 